\title{
THE EFFECT OF THE USE OF DIGITAL MARKETING AND THE EASE OF ACCESS OF ONLINE SHOPPING APPLICATION SERVICES IN IMPROVING PURCHASING POWER OF THE COMMUNITY OF THE MEDAN CITY IN THE ERA REVOLUTION OF THE MARKETING INDUSTRY 4.0
}

\author{
Mila Yulia Herosian ${ }^{1}$, Made Adhiguna Samvara ${ }^{2}$ \\ Manajemen, Fakultas Ekonomi, Universitas Prima Indonesia \\ milayuliaherosian1@gmail.comㄴ, madegunas@gmail.com²
}

\begin{abstract}
The use of data services is not new in the midst of the community because all levels of society can already use online-based services. This is supported by the presence of online shopping applications such as Lazada, Shopee, Tokopedia, Elevenia, Bukalapak, Blibli.com, OLX, Mataharimall.com, and DJ.ID. This research is based on the theory of Marketing Management science related to the development of the digital economy in modern global-based platform organizations as one of the applications that accelerates and facilitates the use of online shopping application services in Indonesia. This research method uses a quantitative descriptive approach with the nature of the research is explanatory. The population in this study is the number of digital marketing service users by 120,856 respondents and the sampling technique using the Slovin formula obtained as many as 100 respondents used in this study. The results obtained in this study are that partially the use of digital marketing obtained $t_{\text {count }}>t_{\text {table }}(1,588>$ $1,290)$ and easy access to services obtained $t_{\text {count }}>t_{\text {table }}(1,434>1,290)$ has $a$ significant positive effect > 0.10 in increasing people's purchasing power Medan city, while simultaneous use of digital marketing and the ease of access of services obtained the value of $F_{\text {count }}>F_{\text {table }}(2.337>2.36)$ has a positive and not significant effect on increasing the purchasing power of the people of Medan City in the era of the marketing industry revolution 4.0
\end{abstract}

Keyword : Digital Marketing, The Ease Of Access, Purchasing Power Of The Community 


\title{
PENGARUH PENGGUNAAN DIGITAL MARKETING DAN KEMUDAHAN AKSES LAYANAN APLIKASI BELANJA ONLINE DALAM PENINGKATAN DAYA BELI MASYARAKAT KOTA MEDAN DI ERA REVOLUSI INDUSTRI MARKETING 4.0
}

\author{
Mila Yulia Herosian ${ }^{1}$, Made Adhiguna Samvara ${ }^{2}$ \\ Manajemen, Fakultas Ekonomi, Universitas Prima Indonesia \\ milayuliaherosian1@gmail.com ${ }^{1}$, madegunas@gmail.com²
}

\begin{abstract}
ABSTRAK
Penggunaan layanan data bukan menjadi hal yang baru di tengah lingkungan masyarakat karena semua lapisan masyarakat sudah dapat menggunakan layanan berbasis online. Hal tersebut didukung dengan adanya aplikasi belanja online seperti Lazada, Shopee, Tokopedia, Elevenia, Bukalapak, Blibli.com, OLX, Mataharimall.com, dan DJ.ID. Penelitian ini didasarkan pada teori ilmu Manajemen Pemasaran terkait dengan perkembangan ekonomi digital dalam organisasi modern berbasis global platform sebagai salah satu aplikasi yang mempercepat dan mempermudah penggunaan layanan aplikasi belanja online di Indonesia. Metode penelitian ini menggunakan pendekatan deskriptif kuantitatif dengan sifat penelitian yaitu explanatory. Populasi dalam penelitian ini adalah jumlah pengguna layanan digital marketing sebesar 120.856 orang responden dan teknik pengambilan sampel dengan menggunakan rumus slovin diperoleh sebanyak 100 orang responden digunakan dalam penelitian ini. Hasil yang diperoleh dalam penelitian ini adalah bahwa secara parsial penggunaan digital marketing diperoleh nilai $t_{\text {hitung }}>t_{\text {tabel }}(1,588>1,290)$ dan kemudahan akses layanan diperoleh nilai $t_{\text {hitung }}>t_{\text {tabel }}(1,434>1,290)$ berpengaruh positif dengan signifikan $>0,10$ dalam meningkatkan daya beli masyarakat kota Medan, sedangkan secara simultan penggunaan digital marketing dan kemudahan akses layanan diperoleh nilai $F_{\text {hitung }}>$ $\mathrm{F}_{\text {tabel }}(2,373>2,36)$ berpengaruh positif dan tidak signifikan dalam meningkatkan daya beli masyarakat Kota Medan di era revolusi industri marketing 4.0
\end{abstract}

Kata Kunci : Digital Marketing, Akses Layanan, Daya Beli Masyarakat 


\section{PRELIMINARY}

The world economy, especially developing countries like Indonesia, is moving towards a digital economy. Technological development is the first driver of this change. Digital marketing is a marketing activity including branding that uses websites, blogs or social media. Digital marketing is becoming very popular among business people along with the growth and advancement of communication technology. Online Shopping makes it easier to shop without spending time and energy. Because of this convenience, online shopping is increasingly in demand. In the beginning, the online shop was one of the forms of activities including buying and selling and marketing of goods or services through an electronic system. Payments are made with a payment system that has been determined and the goods will be sent via the freight forwarding service. Through the online shop, the buyer can see various products offered through the web promoted by the seller. Seeing the number of internet users and the use that has begun to develop shows that the Indonesian people have begun to accept the development of technology, especially in the business sector. The rapid growth of shopping trends through the internet because businesses on the internet do not require too much capital and are quite easy to develop. However, in reality, this facility is not fully used by the people of Indonesia. Indonesian people still like to do transactions traditionally or face to face. Many of the individuals who think that too much risk arises when doing online shopping. The more popular a website, the more confident buyers and trust in the reliability of the website. The third is the price factor. Price is one of the determining factors related to consumer buying decisions. Consumers will buy a product if the price is deemed appropriate by them. Usually, the prices at online stores are cheaper than the prices at traditional stores. This has become the appraisal of online shop application service users prefer it because of the large selection of products and product variations that make online application users choose service providers who dare to offer offers and product promos both from free shipping and alternative payments can be made on-site after the item is received. In addition, application users prefer services that have easier service access and are not difficult in choosing products to buy because it will impact on people's purchasing power and interest in continuity using online shop application services that exist today. The scope of the research focuses on increasing people's purchasing power and maintaining easy access to services from online shopping applications in Indonesia. The formulation of this research problem is how to use digital marketing and easy access to online shopping application services in 
increasing the purchasing power of the people of Medan in the era of the marketing industry revolution 4.0. The formulation of the problem of reducing the hypothesis is that there is a significant influence of the use of digital marketing and easy access to online shopping application services in increasing the purchasing power of the people of Medan in the era of the marketing industry revolution 4.0. The purpose of this study is to examine and analyze the effect of the use of digital marketing to increase the purchasing power of the people of Medan, to study and analyze the effect of easy access to online shopping application services to increase the purchasing power of the people of Medan as well as to examine and analyze the effects of using digital marketing and the ease of access to application services. online shopping to increase the purchasing power of Medan city people in the industrial revolution era 4.0. The research benefits that can be obtained from this research are: publishing a healthy competitive strategy between online shopping application services and providing information about the needs and ease of access to online shopping services to the people of Medan and other cities in Indonesia to users of online shopping application services.

\section{THEORETICAL REVIEW}

\section{Digital Marketing}

Ridwan Sanjaya \& Josua Tarigan (2009: 47) say digital marketing is marketing activities including branding that uses various web-based media such as blogs, websites, e-mails, Adwords, or social networking. Of course, digital marketing isn't just talking about internet marketing. Heidrick \& Struggless (2009: 1) say the development of digital marketing through the web, mobile phones, and gaming devices, offers new access to advertising that is not heralded and is very influential. So why do marketers throughout Asia not shift the use of budgets from traditional marketing such as TV, radio, and print to new technology media and more interactive media? Meyliana (2011) says in her journal entitled "Analysis of Emarketing Strategies and Their Implementation on Rental Companies" said e-marketing is part of e-commerce which is a trading system through the internet, where the internet will continue to provide an up to date nature, so the company can provide product information services offered clearly and easily. This will have a good impact on the progress of the company if this system can be run well. Based on the above understanding, it can be concluded that e-marketing is the process and activity of marketing the company's products and services using electronic media such as the internet.

\section{Ease of Access}

Strauss \& Frost, 2014 say the internet is a global network that is connected to a connected network, where the network generated from an internet network can reach many companies, governments, organizations, and private networks. 
Munawar, 2009 says e-commerce can also be interpreted as a business process using electronic technology that connects companies, consumers and the public in the form of electronic transactions and the exchange/sale of goods, services, and information electronically. Hidayat, 2008 says ecommerce has several standard components that are owned and not owned by business transactions carried out offline, namely: (1) Products: Many types of products that can be sold via the internet such as computers, books, music, clothing, toys, etc. (2) The place to sell a product (a place to sell): the place to sell is the internet which means it must have a domain and host. (3) How to receive orders: email, telephone, SMS, and others. (4) Payment methods: Cash, check, bank draft, credit card, internet payment (for example PayPal). (5) Shipping method: shipping can be done by package, salesman, or downloaded if the product being sold makes it possible (for example software). (6) Customer service: e-mail, on-line forms, FAQs, telephone calls, chat, etc.

\section{Purchasing Power of The Community} Supawi (2016) says purchasing power is the ability of people as consumers to buy goods or services needed. people's purchasing power is marked by an increase or decrease, where purchasing power increases if it is higher than the previous period while purchasing power decreases is characterized by the higher purchasing power of the community than in the previous period. Purchasing power is a person's ability to consume a product. Purchasing power between one person and another must be different. This can be seen from the person's status, employment, income, and so on. Purchasing power is illustrated by real per capita expenditure. Purchasing power also has a close relationship with an item or product. If the goods or products have cheap prices, the people's purchasing power of the goods will also increase. This applies as in the law of demand. Demand is the number of goods demanded at a certain market at a certain price level and within a certain period supported by purchasing power. Purchasing power is the ability of consumers to buy the desired amount of goods, which are usually expressed in terms of money.

\section{Conceptual Framework}

In business activities, there are many challenges and difficulties, including marketing activities that rely on or take advantage of the progress of this digital technology. The implementation of digital marketing has several obstacles that will definitely be faced when going to digital marketing efforts. While the interest or interest of the audience or all internet universe users to see the contents of the advertising content. Surely they will avoid or try to avoid advertising that is in cyberspace. If we don't solve this problem or run digital marketing without a strategy, then our marketing activities will be useless. The best way is to draft the ad. Besides that, you can use short films with humor or comedy, inspiration, motivation or other 
things that the audience wants. Make your ad content more than just advertising, content that not only conveys information about the product but also other information needed by the user or audience. The information gap in the community is still very large, especially when compared between urban communities and rural communities. This is inseparable from the still lack of access to equitable distribution of information, the thing that is most felt is Indonesia's hilly geographical position, as well as the low portion of the community in terms of education, especially in knowledge in technology. Based on the explanation above, it can be made systematically the relationship between the influence of the use of digital marketing and the ease of access to online shopping application services in increasing the purchasing power of the people of Medan in the era of the marketing industry revolution 4.0 with the framework in Figure 1. below:

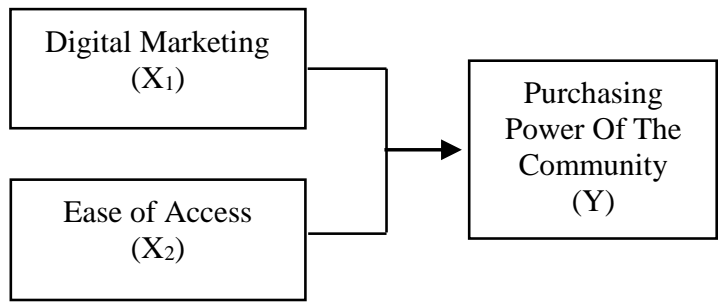

Figure 1. Research Framework Model

\section{RESEARCH METHODS}

The approach used in this research is a survey approach that is the activity of collecting as much data as possible about the facts that are supporting the research with the intention to find out the status, the symptoms of finding common ground by comparing with the standards that have been selected or determined (Sugiyono, 2010). The type of research that is used is quantitative descriptive research. Quantitative descriptive research is gathering data to test hypotheses or answer questions about the final status of research subjects (Sugiyono, 2010). The nature of the research is explanatory research. Sugiyono (2010) says that explanatory research is research that aims to explain the position of the variables studied as well as the relationship between one variable with another variable.

\section{Population and Sample.}

The population in this study is the number of users of digital marketing services and who use these services for online shopping or application users who also market their products

Table 1.

Population of Digital Service Users

\begin{tabular}{ccc}
\hline No & $\begin{array}{c}\text { Online Shop Service } \\
\text { Application }\end{array}$ & $\begin{array}{c}\text { Total Digital } \\
\text { Population }\end{array}$ \\
\hline 1 & Lazada.co.id & 21235 \\
2 & Blibli.com & 15556 \\
3 & Tokopedia.com & 14401 \\
4 & Elevania.co.id & 12872 \\
5 & MatahariMall.com & 12520 \\
6 & Shopee.co.id & 11301 \\
7 & Bukalapak.com & 10407 \\
8 & Zalora.co.id & 9052 \\
9 & Qoo10.co.id & 7689 \\
10 & Blanja.com & 5823 \\
\hline & Total & 120856 \\
\hline
\end{tabular}

Source : comScore MMX Multi-Platform June 2017

Sampling using a non-probability sampling approach. The type of 
sampling chosen was accidental sampling with the type of qualified volunteer sample, meaning that respondents who were met by the researchers were willing to voluntarily become respondents and meet the criteria of researchers (Morrisan, 2014). The sampling technique used in this study using the Slovin formula. Sanusi (2011: 101) says the Slovin formula is used to determine the sample size of a known population, which is as follows:

$n=\frac{N}{1+N(e)^{2}}=\frac{120856}{1+120856(0,1)^{2}}=\frac{120856}{1209,56}=99,91 \approx 10$

Where:

$\mathrm{n}=$ sample size

$\mathrm{N}=$ population size

$\mathrm{e}=$ percentage error $(10 \%)$

The results of calculations using the Slovin formula obtained a sample of 100 people who use online shopping application services in the city of Medan.

\section{Data Collection Technique}

Data collection techniques used by interviews (interviews) that is conducting interviews (interviews) to those who are competent or ask for the help provided by this research, questionnaire (questions) that are giving questions to users of online purchasing application services that are used as samples in research this. Study documentation which contains and analyzes data and information obtained from documents obtained from research journals.

Data Source Type. Types and sources of data in this study are primary and ossecondary data with the following explanation: Primary data, data obtained directly from research respondents for further processing by researchers and obtained from questionnaire distribution in order to obtain clear information. Secondary data is supplementary data related to the research problem.

\section{Research Identification and Variables} Identification and operations required dependent variable increased community purchasing power (Y), the independent variable consists of the use of digital marketing (X1), easy access to services (X2).

Table 2. Variables, Indicators and Measurement Scale

\begin{tabular}{cll}
\hline Variables & \multicolumn{1}{c}{ Indicators } & Measurement Scale \\
\hline & 1. & Website Engagement \\
Digital Marketing & 2. CTR (Click-Through-Rate) & Interval \\
$\left(\mathrm{X}_{1}\right)$ & 3. Conversion Rate & \\
& 4. Social Engagement & \\
& 1. Network latency & \\
Ease of Access & 2. Utilisasi bandwidth & Interval \\
$\left(\mathrm{X}_{2}\right)$ & 3. Throughput & \\
& 4. Packet loss & \\
& 5. Availability & \\
& 6. Average downtime & \\
\hline
\end{tabular}




\begin{tabular}{|c|c|c|}
\hline $\begin{array}{l}\text { Purchasing Power Of The Community } \\
\text { (Y) }\end{array}$ & $\begin{array}{ll}\text { 1. } & \text { Income Level } \\
\text { 2. } & \text { Education Level } \\
\text { 3. } & \text { Level of Need } \\
\text { 4. } & \text { Community Habits } \\
\text { 5. } & \text { Price of Goods } \\
\text { 6. } & \text { Mode } \\
\end{array}$ & Interval \\
\hline
\end{tabular}

\section{Data Analysis Method}

Statistical analysis used in this study uses statistical analysis with multiple linear regression analysis or multiple linear regression analysis used to test the linear relationship between two or more independent variables $(\mathrm{X})$ with the dependent variable (Y). (Ghozali, 2013).

\section{Test of Validity and Reliability}

\section{Validity Test}

a. Validity Test of Digital Marketing Variables (X1)

To test the validity of the Digital Marketing (X1) variable, the correlation value is greater than the rtable value of 0.30 and the significant value is less than 0.05 , which means all questions are declared valid as in Table 3 below:

Table 3.

Test the Validity of Digital Marketing Variables (X1)

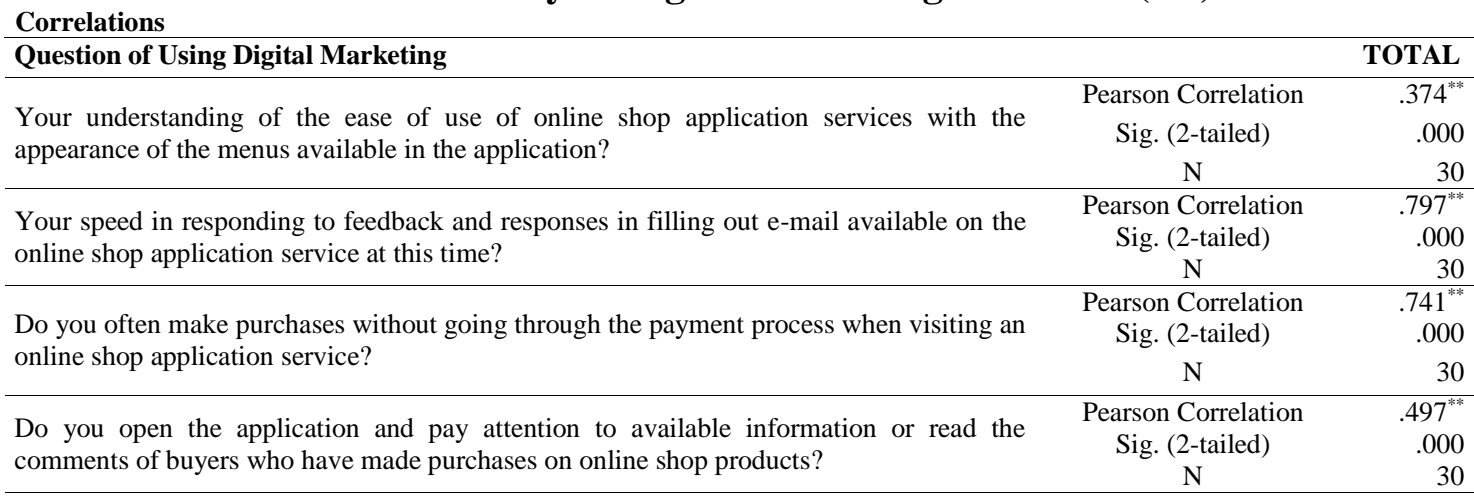

**. Correlation is significant at the 0.01 level (2-tailed).

Source: Primary Data Processed (2019)

b. Test the Validity of Variable Ease of Service Access (X2). To test the validity of the ease of service access variable (X2), the correlation value is greater than the $r_{\text {table }}$ value of 0.30 and the significant value is less than 0.05 , which means all questions are declared valid as in Table 4 below :

Table 4. Test the Validity of Variables Ease of Service Access (X2)

Correlations

\begin{tabular}{|c|c|c|}
\hline Questions on Ease of Service Access & & TOTAL \\
\hline \multirow{3}{*}{$\begin{array}{l}\text { Do you often experience access failures when you log in and visit online shop application } \\
\text { services? }\end{array}$} & Pearson Correlation & $.536^{* *}$ \\
\hline & Sig. (2-tailed) & .000 \\
\hline & $\mathrm{N}$ & 30 \\
\hline
\end{tabular}




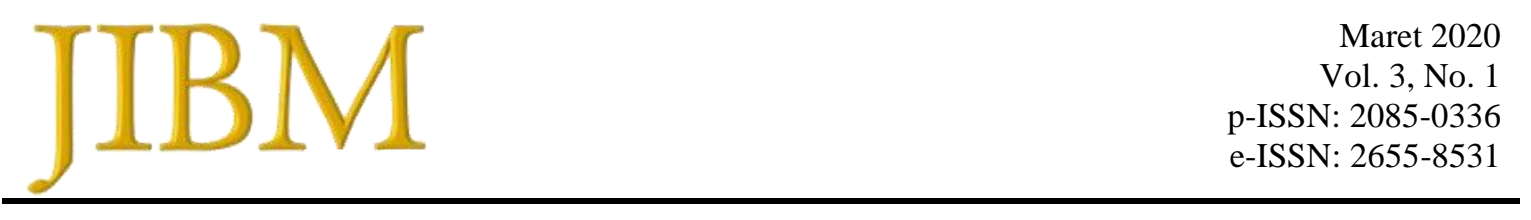

\begin{tabular}{|c|c|c|}
\hline access when using the application's services? & $\begin{array}{c}\text { Sig. (2-tailed) } \\
\text { N }\end{array}$ & $\begin{array}{r}.000 \\
30\end{array}$ \\
\hline \multirow{3}{*}{$\begin{array}{l}\text { Service access time limitations to affect you using service applications for downloading } \\
\text { the types of products available at the online shop application service? }\end{array}$} & Pearson Correlation & $.557^{* *}$ \\
\hline & Sig. (2-tailed) & .000 \\
\hline & $\mathrm{N}$ & 30 \\
\hline \multirow{3}{*}{ Your assessment of the quality of access to online shop services used today? } & Pearson Correlation & $.469^{* *}$ \\
\hline & Sig. (2-tailed) & .000 \\
\hline & $\mathrm{N}$ & 30 \\
\hline \multirow{3}{*}{$\begin{array}{l}\text { The availability of online shop application services makes it easy for you to make product } \\
\text { purchases both in the payment process and order delivery? }\end{array}$} & Pearson Correlation & $.579^{* *}$ \\
\hline & Sig. (2-tailed) & .000 \\
\hline & $\mathrm{N}$ & 30 \\
\hline \multirow{3}{*}{$\begin{array}{l}\text { The deadline for payment after ordering the product in the online shop application } \\
\text { service? }\end{array}$} & Pearson Correlation & $.357^{* *}$ \\
\hline & Sig. (2-tailed) & .000 \\
\hline & $\mathrm{N}$ & 30 \\
\hline
\end{tabular}

**. Correlation is significant at the 0.01 level (2-tailed).

Source: Primary Data Processed (2019)

c. Validity Test of Community Purchasing Power Variables (Y)

To test the validity of the variable public purchase power (Y) obtained correlation values greater than $r_{\text {value }}$ 0.30 and a significant value smaller than 0.05 which means all questions are declared valid as in Table 5 below:

\section{Table 5. Test the Validity of Community Purchasing Power Variables (Y)}

\section{Correlations}

\begin{tabular}{lcr}
\hline The Public Purchasing Power Question & TOTAL \\
\hline Available price suitability in the online application with the income you have & Pearson Correlation & $.408^{* *}$ \\
now? & Sig. (2-tailed) & .000 \\
& $\mathrm{~N}$ & 30 \\
\hline Your ability to assess product quality before making a purchase at the online & Pearson Correlation & $.531^{* *}$ \\
shop application? & Sig. (2-tailed) & .000 \\
& $\mathrm{~N}$ & 30 \\
\hline Do you regularly make purchases of products available in the online shop & Pearson Correlation & $.672^{* *}$ \\
application? & Sig. (2-tailed) & .000 \\
& $\mathrm{~N}$ & 30 \\
\hline Your habit to make in online shop purchases according to current needs? & Pearson Correlation & $.406^{* *}$ \\
& Sig. (2-tailed) & .000 \\
& $\mathrm{~N}$ & 30 \\
\hline Are you often compare the prices of products owned by each online shop & Pearson Correlation & $.791^{* *}$ \\
application service? & Sig. (2-tailed) & .000 \\
& N & 30 \\
\hline Fashion and mode currently influence you to purchase products offered in the & Pearson Correlation & $.819^{* *}$ \\
online shop application? & Sig. (2-tailed) & .000 \\
& N & 30 \\
\hline$* *$ Correlation is significant at the 0.01 level
\end{tabular}

**. Correlation is significant at the 0.01 level (2-tailed).

\section{Source: Primary Data Processed (2019)}

\section{Reliability Test}

Testing the reliability of the instrument using the cronbach alpha formula because the research instrument was in the form of a questionnaire and multilevel scale. If alpha is between $0.70-0.90$ then reliability is high. If alpha is $0.50-0.70$, the reliability is moderate. If alpha $<0.50$ then reliability is low. 
Table 6. Reliability Test for Variables X1, X2 \& Y

Reliability Statistics

\begin{tabular}{lcc}
\hline \multicolumn{1}{c}{ Variable } & Cronbach's Alpha & N of Items \\
\hline Digital Marketing & 0.734 & 4 \\
Ease of Access & 0.855 & 6 \\
$\begin{array}{l}\text { Purchasing Power Of } \\
\text { The Community }\end{array}$ & 0.981 & 6 \\
\hline
\end{tabular}

Source: Primary Data Processed (2019)

\section{Classical Assumption Testing}

The classic assumption test is a way to find out whether the regression model obtained can produce a good linear estimator. If it meets the classical assumptions, it means the ideal (not biased) regression model (Best Linear Unbias Estimator / BLUE)

\section{Multicollinearity Test.}

Umar (2010: 80) says multicollinearity test is useful to know whether the proposed regression model has found strong correlations between independent variables. If there is a strong correlation, there is a multicollinearity problem that must be overcome. Umar (2010:81-82) says multicollinearity test can be known using 2 formulas, i.e :

1. Using VIF (Variance Inflation Factor). Umar (2010: 81) says the criterion is that if the VIF value is close to 10 then there will be no multicollinearity and vice versa if VIF is away from the number 10 then there will be multicollinearity. Umar (2010: 81) says that to calculate the VIF for the coefficient of the independent variable using the formula: VIF = 1 / (1-R2)

2. Using Tolerance values. Umar (2010: 82) says this test criterion is that if the tolerance value is greater than 0.1 then multicollinearity does not occur and vice versa if the tolerance value is smaller than 0.1 then multicollinearity occurs. Umar (2010: 81) says that to calculate TOL with the formula: TOL $=(1-$ $\mathrm{R}^{2}$ ) 
Table 7.

Multicollinearity Test

\begin{tabular}{|c|c|c|c|}
\hline \multirow[t]{2}{*}{ Model } & & \multicolumn{2}{|c|}{ Collinearity Statistics } \\
\hline & & Tolerance & VIF \\
\hline \multirow{3}{*}{1} & (Constant) & & \\
\hline & Digital Marketing (X1) & .999 & 1.001 \\
\hline & Ease of Access (X2) & .999 & 1.001 \\
\hline
\end{tabular}

\section{Normality Test}

Umar (2010: 77) says suggested that the normality test is useful for knowing whether the dependent variable, independent or both are normally distributed, close to normal or not. If the data are not normally distributed, then nonparametric analysis can be used. Umar (2010: 77-79) says normality tests are divided into 2 types of testing, i.e :

\section{Test using Graphics. Test using the chart is divided into 2 namely:} a. Probability-plot graph

The criterion is that if the data spreads around the diagonal line, and there is no data that is located far from the diagnostic line, the data is said to be normal.

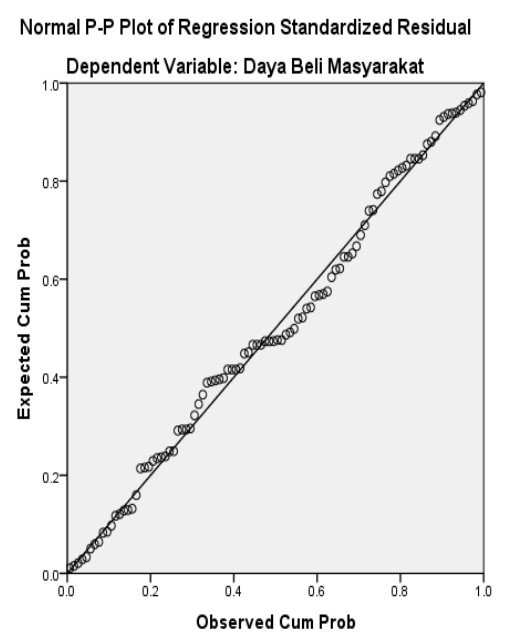

Figure 1.Probability-plot graph

\section{b. Histogram Graph}

The criterion is that if the data spreads to form a bell shape and the distribution of the data does not go right, then the data is said to be normal.

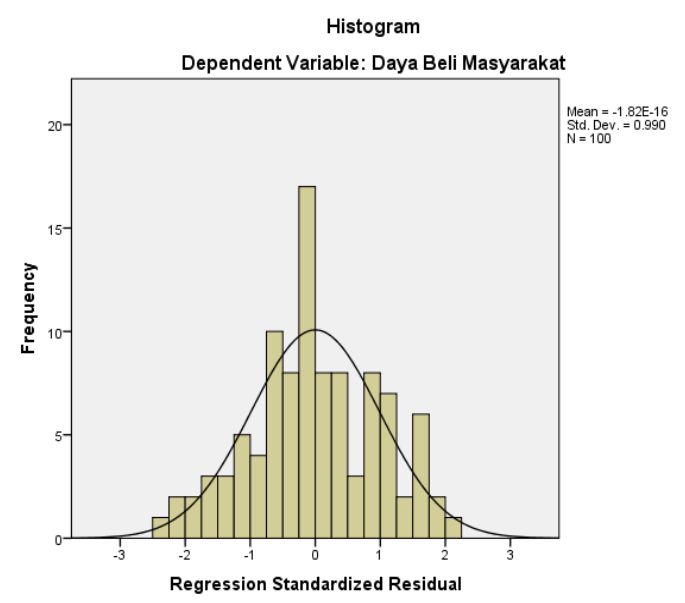

Figure 2. Histogram Graph

2. Test using statistics. Test using statistics is by using the Kolmogorov-Smirnov test. This test criterion is if the value is on Asymp. Sig. (2-tailed), more than 0.05 , the data is said to be normally distributed and if the Asymp value. Sig. (2-tailed), smaller than 0.05, the data are said to be not normally distributed. 
Table 8.

Kolmogorov-Smirnov Test

One-Sample Kolmogorov-Smirnov Test

\begin{tabular}{llr}
\hline $\mathrm{N}$ & $\begin{array}{r}\text { Unstanc } \\
\text { Resi }\end{array}$ \\
$\begin{array}{ll}\text { Normal Parameters } \\
\text { Most } \mathrm{b}\end{array}$ & $\begin{array}{l}\text { Mean } \\
\text { Std. Deviation }\end{array}$ \\
$\begin{array}{l}\text { Absolute } \\
\text { Differences }\end{array}$ & $\begin{array}{l}\text { Positive } \\
\text { Kolmogorov-Smirnov Z }\end{array}$ & Negative \\
Asymp. Sig. (2-tailed) & \\
\hline $\begin{array}{l}\text { a. Test distribution is Normal. } \\
\text { b. Calculated from data. }\end{array}$
\end{tabular}

Source: Primary Data Processed (2019)

\section{Heteroscedasticity Test}

Umar (2010:82) says a heteroscedasticity test was carried out to find out whether, in the regression model, there was an inequality of variance from the residuals of one observation to another. If the variance from one observation residual to another observation is fixed, it is called homoscedasticity, while for different variances it is called heteroscedasticity. Umar (2010: 84) says heteroscedasticity test is divided into 2 tests i.e :

1. Test using graphics. Testing using graphics is by using Scatterplot charts. Umar (2010: 84) says the criterion is that if the irregular distribution of data is not close to each other and away from line 0 , heteroscedasticity will occur.

2. Test with Glejser. Testing using statistics is to use the Glejser Test. The criteria are if the Asymp value. Sig. smaller than 0.05 , the data occurs heteroscedasticity.

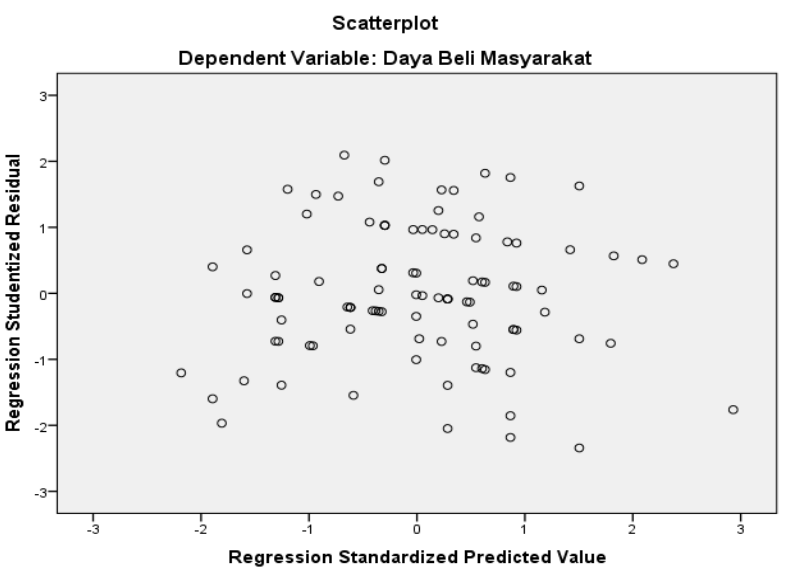

Figure 3. Scatterplot Graph

Table 9.

Glejser Test

\begin{tabular}{lll}
\multicolumn{2}{l}{ Coefficients $^{\mathbf{a}}$} \\
Model & \multicolumn{2}{l}{ Sig. } \\
\hline & & \\
\hline & (Constant) & .315 \\
& Digital Marketing & .350 \\
& Ease of Access & .880 \\
\hline
\end{tabular}

a. Dependent Variable: RES2

Source: Primary Data Processed (2019)

In Table 9 above, it is known that the significant value of the digital marketing variable (X1) of 0.350 is greater than 0.05 , meaning that there is no heteroscedasticity on the digital marketing variable (X1). Meanwhile, it is known the significance value of the service access variable (X2) which is 0.880 is greater than 0.05 , meaning that there is no heteroscedasticity on the service access variable (X2).

\section{Multiple Linear Regression Analysis Test}

Siregar (2014: 405) says the data analysis model in this study is a multiple regression analysis where the application of multiple regression methods uses the number of 
independent variables used more than one that affects one dependent variable. Siregar (2014: 405) says the equation of the multiple linear regression equation is as follows:

$$
\mathbf{Y}=\mathbf{a}+\mathbf{b}_{1} \mathbf{X}_{1}+\mathbf{b}_{2} \mathbf{X}_{2}+\mathbf{e}
$$

Information :

$$
\begin{aligned}
\mathrm{Y}= & \text { Purchasing Power Of } \\
& \text { The Community } \\
\mathrm{a}= & \text { constant } \\
\mathrm{b} 1,2= & \text { Variable Regression Coe- } \\
& \text { fficient }(\mathrm{X} 1, \mathrm{X} 2) \\
\mathrm{X} 1= & \text { Digital Marketing } \\
\mathrm{X} 2= & \text { Ease of Access } \\
\mathrm{e} \quad= & \text { Standard Error }(5 \%)
\end{aligned}
$$

\begin{tabular}{|c|c|c|c|}
\hline \multirow{3}{*}{ Model } & fficient & & \\
\hline & \multicolumn{2}{|c|}{$\begin{array}{c}\text { Unstandardized } \\
\text { Coefficients }\end{array}$} & \multirow[t]{2}{*}{ Sig. } \\
\hline & $\mathrm{B}$ & Std. Error & \\
\hline \multirow{3}{*}{$\begin{array}{ll} & \text { (Constant) } \\
& \text { Digital } \\
1 & \text { Marketing } \\
\text { Ease of } \\
\text { Access }\end{array}$} & 12.156 & 2.865 & .000 \\
\hline & .215 & 135 & .116 \\
\hline & .196 & . 137 & .155 \\
\hline
\end{tabular}

Table 10.

Research Analysis Model Test Results

Source: Primary Data Processed (2019)

Based on Table 10 above, the multiple linear regression equation is obtained as follows:

$$
\mathrm{Y}=12,156+0,215 \mathrm{X} 1+0,196 \mathrm{X} 2+\mathrm{e}
$$

The regression equation model above can be interpreted that a constant of 12,156 has the meaning that if the value of the independent variable that is digital marketing and access to service is zero is considered to be non-existent then people's purchasing power is equal to $12,156 \%$. Digital marketing (X1) has a regression coefficient of 0.215 and is positive, this means that every one percent increase in digital marketing variables will give an increase in people's purchasing power of 0.215 or $21.5 \%$ if other variables are assumed to be constant. This provides an explanation that digital marketing is a part of the change in the direction of increasing community purchasing power. Service access (X2) has a regression coefficient of 0.196 and has a positive value, this means that every 1 percent increase in the variable ease of access to services will give an increase in public purchasing power of 0.196 or $19.6 \%$ if other variables are assumed to be constant. This provides an explanation that the ease of access to services is part of the change in the direction of increasing the community purchasing power.

\section{Coefficient of Determination $\left(\mathbf{R}^{\mathbf{2}}\right)$}

Ghozali (2011: 97) says that the coefficient of determination essentially measures how far the ability of the model in explaining the variation of the dependent variable. The coefficient of determination is between zero and one. A small $\mathrm{R}^{2}$ value means that the ability of the independent variables to explain the variation of the dependent variable is very limited. A value close to one means that the independent variables provide almost all of the information needed to predict variations in the dependent variable. Gujarati in Ghozali (2011: 97-98) says if in the empirical test the adjusted $\mathrm{R}^{2}$ value is negative, then the adjusted $R^{2}$ value is considered 
zero. Mathematically if the value of $\mathrm{R}^{2}$ $=1$, then adjusted $\mathrm{R}^{2}=\mathrm{R}^{2}=1$, whereas if the value of $R 2=0$, then adjusted $R^{2}$ $=(1-\mathrm{k}) /(\mathrm{n}-\mathrm{k})$. If $\mathrm{k}>1$, then adjusted $\mathrm{R}^{2}$ will be negative.

Table 11. Determination Coefficient Test Results

Model Summary

\begin{tabular}{llccc}
\hline Model & $R$ & R Square & $\begin{array}{c}\text { Adjusted R } \\
\text { Square }\end{array}$ & $\begin{array}{c}\text { Std. Error of the } \\
\text { Estimate }\end{array}$
\end{tabular}

1 $.216^{\mathrm{a}} \quad .047$ .027 3.07569

a. Predictors: (Constant), Digital Marketing, Ease of Access Source: Primary Data Processed (2019)

Based on the test results above, it can be seen that the $R^{2}$ value is 0.216 and the Adjusted $\mathrm{R}^{2}$ value is 0.027 . The coefficient of determination in this study is seen based on the $\mathrm{R}^{2}$ value of 0.027 which means that variations in digital marketing variables and ease of access are able to explain $2.7 \%$ of variable variations purchasing power of the community while the remaining $97.3 \%$ is explained by other variables not researched in this study.

\section{Hypothesis Testing}

\section{Simultaneous Hypothesis Testing (F Test)}

$\mathrm{F}$ test (simultaneous test) is carried out to see together the influence or positive and significant relationship of independent variables $(\mathrm{X} 1, \mathrm{X} 2)$ in the form of digital marketing variables and service access to the dependent variable (Y) in the form of variables in increasing the purchasing power of the
Medan city community in the era marketing industry revolution 4.0.

Table 12.

\section{F-Test Results (Simultaneous)}

\begin{tabular}{|c|c|c|c|}
\hline \multicolumn{4}{|c|}{ ANOVA $^{a}$} \\
\hline Model & & $\mathrm{F}$ & Sig. \\
\hline \multirow{3}{*}{ tour } & Regression & 2.373 & $.099^{\mathrm{b}}$ \\
\hline & Residual & & \\
\hline & Total & & \\
\hline
\end{tabular}

a. Dependent Variable: Purchasing Power Of The Community b. Predictors: (Constant), Digital Marketing, Ease of Access Source: Primary Data Processed (2019)

Simultaneous testing or F-test aims to see how the influence of digital marketing and easy access to services in improving the purchasing power of the Medan city community in the era of the marketing industry revolution 4.0. Based on the test results above, the

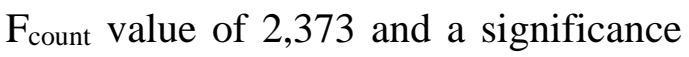
value of 0.099 is obtained. $\mathrm{F}_{\text {count }}$ value will be compared with $\mathrm{F}_{\text {table }}$ value that is equal to 2.36 (obtained by seeing $F_{\text {table }}$ with criteria df $1=2$ and df $2=$ greater than 97), the results obtained are $F_{\text {count }}>$ $F_{\text {table }}(2.337>2.36)$ and a significance value of $0.099<0.10$ so that it can be concluded that digital marketing and access to services together have a positive and significant effect in increasing the purchasing power of the community of Medan in the era of the marketing industry revolution 4.0

\section{Partial Hypothesis Testing (t-Test)}

T-test was conducted to partially test the independent variables consisting of digital marketing (X1) and ease of access (X2) had a positive and significant influence in increasing the 
purchasing power of the Medan city community in the era of the marketing industry revolution 4.0

Table 13.

\section{T-Test Results (Partial)}

\section{Coefficients $^{\mathrm{a}}$}

\begin{tabular}{|c|c|c|c|}
\hline Model & & $\mathrm{t}$ & Sig. \\
\hline \multirow{3}{*}{1} & (Constant) & 4.243 & .000 \\
\hline & Digital Marketing & 1.588 & .116 \\
\hline & Ease of Access & 1.434 & .155 \\
\hline
\end{tabular}

a. Dependent Variable: Purchasing Power Of The Community Source: Primary Data Processed (2019)

Based on Table 13 above, it appears that:

1. Partial hypothesis testing of digital marketing variables from the table can be seen the t-value of digital marketing variables (X1) is 1.588 with a significance of 0.116 . So the results of the study show the hypothesis $\mathrm{H} 1$ is accepted because $\mathrm{t}_{\text {count }}>\mathrm{t}_{\text {table }}(1.588>1.290)$ and significantly greater than 0.10 which means that the digital marketing variable (X1) has a positive and significant effect in increasing the purchasing power of the community (Y) of Medan city in the revolutionary era marketing industry 4.0

2. Partial hypothesis testing ease of access variables from the table can be seen the t-value of the ease of access variable (X2) is 1.434 with a significant of 0.155 . So the results of the research show that the hypothesis $\mathrm{H} 1$ is accepted because $t_{\text {count }}>t_{\text {table }}(1.434>1.290)$ and the significant is greater than 0.10 which means that the service access variable (X2) has a positive and significant effect in increasing the purchasing power of the community (Y) of Medan city in the revolutionary era marketing industry 4.0.

Based on the significant value of digital marketing variables and ease of access, it can be seen that the most dominant factor influencing the increase in the purchasing power of the community of Medan city in the era of the marketing industry revolution is the digital marketing variable (X1).

\section{Conclusions and Suggestions}

1. Community understanding is still lacking in the use of digital marketing as seen from its ability to use services available in online shopping applications such as sales and product purchase services. Besides marketing products using online shopping applications are often constrained in choosing products because of the limited products available and the features that are displayed are still less attractive to buyers, therefore service providers must make service products to improve purchasing power of the community.

2. Ease of service access is one of the ratings of online shopping application users to make product purchases and product sales. The density of service access will have an impact on the decline in the public interest to enter the product service application and choose 
other online shopping application services. The experience of buyers in accessing online shopping application services can be seen from how often they use and access online shopping application services.

3. Factors that influence the increase in people's purchasing power are the use of digital marketing which has the most dominant influence in increasing purchasing power of the community because the use of digital marketing does not have to have understanding and knowledge but the ability to manage and utilize online shopping application services properly in order to have power pull-on products and product choices so that the use of digital marketing can be maximized.

4. Researchers suggest for users of online-based services use digital marketing services as well as possible because there are so many online shopping applications popping up now. This proves competition between online-based service providers to maintain the characteristics of available products so that product users do not switch to other online shopping products.

5. The industrial revolution 4.0 is an era of change for service providers who are still using conventional systems to immediately innovate and change into digital-based services in addition to making it easier for service users to also provide solutions for producers to be able to interact directly with prospective buyers in purchasing and selling systems or bidding systems.

\section{BIBLIOGRAPHIC \\ Book}

Creeber, G. and Martin, R., (ed)., 2009. Digital Cultures: Understanding New Media, Berkshire- England: Open University Press.

Ghozali, Imam, 2013, Aplikasi Analisis Multivariate dengan Program SPSS, Universitas Diponegoro

Hidayat, Taufik, 2008, Panduan Membuat Toko Online dengan OSCommerce, Mediakita, Jakarta

Husein, Umar. 2010. Metode Penelitian Untuk Skripsi dan Tesis Bisnis Edisi 11. Jakarta: PT Raja Grafindo Persada.

Munawar, Kholil. 2009. E-commerce. http://staff.uns.ac.id.

Ridwan Sanjaya \& Josua Tarigan. 2009. Dasar-dasar Pemasaran. Jakarta: PT Indeks Kelompok Gramedia, 2004 hal 600

Strauss, Judy., Frost, Raymond. 2009. E-Marketing -5/E. New Jersey: Pearson Pretince Hall

Sugiyono, 2011, Metode Penelitian, Kombinasi Mixed Methods, Alfabeta, Bandung

Supawi Pawenang, 2016, Modul Perkuliahan Lingkungan Ekonomi Bisnis, Surakarta: Program Pascasarjana, UNIBA 
Williams, B.K. and Sawyer, S.C. 2011. "Using Information Technology: A Practical Introduction to Computers \& Communications. (9th edition)". New York: McGraw-Hill

\section{Journal}

Armesh, H. et., al. 2010. Impact of Online/Internet Marketing on Computer Industry in Malaysia in Enhancing Consumer Experience. International. Journal of Marketing Studies, Vol. 2, No.2, hal 78.

Budiman, Johan (2018). Pengaruh Daya Beli Masyarakat dan Strategi Pemasaran Dalam Meningkatkan Hasil Penjualan Pada Bisnis Property. Jurnal Keilmuan dan Aplikasi Teknik. UNISTEK, Edisi 5. No.1

Dehkodari, J. G. 2012. A Conceptual Study on E-marketing and Its Operation on Firm's Promotion and Understanding Customer's Response. International Journal of Business and Management, Vol.7, No.19, hal 115.
Meyliana (2011). Analisa Strategi EMarketing dan Implementasinya pada Rental Company. Jurnal Binus Business Review. Vol 2, hal 32.

Rapitasari, Diana (2016). Digital Marketing Berbasis Aplikasi Sebagai Strategi Meningkatkan Kepuasan Pelanggan. Jurnal $\begin{array}{lll}\text { Cakrawala Vol.10. No.2 } & \end{array}$ Desember 2016. hal 107-112

Ruth, Emyana (2015). Deskripsi Kualitas Layanan Jasa Akses Internet di Indonesia dari Sudut Pandang Penyelenggara. Jurnal Buletin Pos dan Telekomunikasi, Vol.11 No.2 Juni 2013 : 137-146

\section{Website}

- https://idseducation.com/articles/ 5-performance-indicatorskeberhasilan-digital-marketing/

- https://www.idea.or.id/ 